\title{
SARANA DAN PRASARANA
}

Diajukan untuk memenuhi salah satu tugas kelompok pada mata kuliah MANAJEMEN SEKOLAH yang di simpu oleh :

Wahyu Bagja Sulfemi, M.Pd

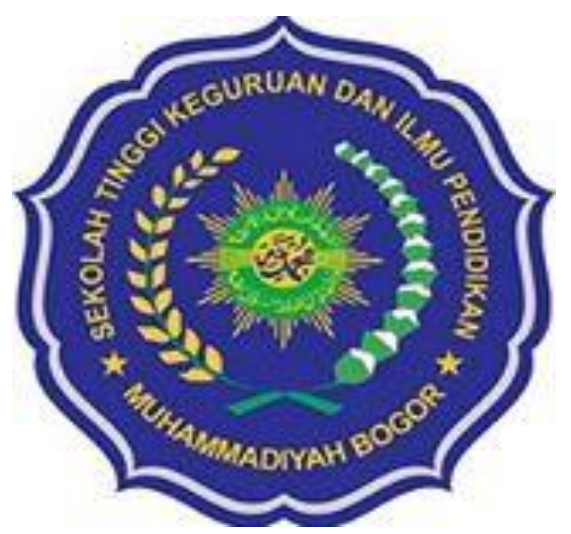

Disusun oleh :

Dewi Paramita

NIM: 0142S1A018039 


\begin{abstract}
ABSTRAK
Sarana dan prasarana pendidikan suatu faktor menunjang dalam proses kagiatan belajar mengajar, dalam suatu instansi sekolah sarana dan prasarana nya terpenuhi maka proses belajar mengajar nya pun akan efektif dan efesien.

Dalam persektif pemerintah, kegiatan manajemen sarana dan pendidikan setidaktidaknya memiliki delapan mata rantai kegiatan yaitu : 1) perencanaan sarana dan rasarana pendidikan; 2) pengadaan sarana dan prasarana pendidikan; 3) penyaluran sarana dan prasaran pendidikan; 4) penyimpanan sarana dan prasarana pendidikan; 5) pemeliharaan sarana dan prasarana pendidikan; 6) pendayagunaan sarana dan prasarana pendidikan; 7) inventarisasi sarana dan prasarana pendidikan; 8) penghapusan sarana dan prasarana pendidikan dengan tujuan untuk mencapai tingkat pengamanan yang semaksimal mungkin terhada kekayaan milik negara. Matin (2019:3)
\end{abstract}




\section{PEMBAHASAN MATERI}

\section{PENGERTIAN}

Sarana dan prasarana merupakan salah satu sumber daya yang penting dalam menunjang proses pembelajaran di sekolah. Keberhasilan program pendidikan di sekolah sangat dipengaruhi oleh kondisi sarana dan prasarana pendidikan yang dimiliki sekolah dan oleh optimalisasi pengelolaan dan pemanfaatannya. Matin (2019:1)

Dalam persektif pemerintah, kegiatan manajemen sarana dan pendidikan setidak-tidaknya memiliki delapan mata rantai kegiatan yaitu : 1) perencanaan sarana dan rasarana pendidikan; 2) pengadaan sarana dan prasarana pendidikan; 3) penyaluran sarana dan prasaran pendidikan; 4) penyimpanan sarana dan prasarana pendidikan; 5) pemeliharaan sarana dan prasarana pendidikan; 6) pendayagunaan sarana dan prasarana pendidikan; 7) inventarisasi sarana dan prasarana pendidikan; 8) penghapusan sarana dan prasarana pendidikan dengan tujuan untuk mencapai tingkat pengamanan yang semaksimal mungkin terhada kekayaan milik negara. Matin (2019:3)

Pemerintah mengelurkan peraturan pemerintah Nomor 19 Tahun 2005 junto Nomor 32 Tahun 2013 tentang Standar Sarana dan prasarana Sekolah. Pada Bab VII Pasal 42 PP 32/2013 disebutkan bahwa; (1) setiap satuan pendidikan wajib memiliki sarana yang meliputi perabot, peralatan pendidikan, media pendidikan, buku dan sumber belajar lainnya, bahan habis pakai, serta erlengkaan lain yang diperlukan untuk menunjang proses pembelajaran yang teratur dan berkelanjutan. (2) setiap satuan pendidikan wajib memiliki rasarana yang meliuti lahan, ruang kelas, ruang pimpinan satuan pendidikan, ruang pendidik, ruang tata usaha, ruang perpustakaan, ruang laboraturium, ruang bengkel kerja, ruang unit produksi, ruang kantin, instalasi daya dan jasa, tempat berolahraga, tempat beribadah, tempat bermain, tempat berkreasi,dan ruang/tempat lain yang diperlukan unuk menunjang roses embelajaran yang terratur dan berkelanjutan. Matin, (2019: 3-4)

Agar sarana dan rasarana pendidikan yang dibutuhkan sekola berfungsi optimal dalam mendukung pembelajaran disekolah, diperlukan warga sekolah (kepala sekolah, guru, dan tenaga administrasi) yang memahami dan mampu mengelola sarana dan prasarana pendidikan secara profesional. Salah satu kometensi tersebut adalah kometensi manajerial keala sekolah yaitu keala sekolah harus memiliki kemampuan mengelola sarana dan prasarana sekolah dalam rangka pendayagunaannya secara optimal. Matin, (2019:4) 


\section{PERENCANAAN KEBUTUHAN SARANA DAN PRASARANA PENDIDIKAN}

\section{A. Analisis Kebutuhan Sarana Dan Prasarana Pendidikan}

Analisis merupakan kegiatan membandingkan antara data yang ada di laangan dengan data yang seharusnyya ada menurut pembakuan sarana dan prasarana pendidikan. Hasil analisis akan bertumpu pada dua informasi tentang ada kesesuaian dan tidak ada kesesuaian. Jika analisis menghasilkan infomasi tidak ada kesesuaian, maka ada dua kemungkinan yaitu sarana dan prasarana keadaanya kurang atau keadaanya berlebih. Jika keadaan sarana dan prasarana kurang, maka hal ini berarti ada kebutuhan terhadap sarana ddan prasarana pendidikan dapat pula ditentukan berdasarkan data hasil proyeksi penduduk usia sekolah yang akan masuk menjadi siswa baju.

Untuk menghitung jumlah dan mutu sarana dan prasarana pendidikan yang dibutukan, harus ada survei penduduk dan pendidikan. Pada kegiatan ini, kita harus ada survei penduduk dan pendidikan. Pada kegiatan ini, kita harus mengumpulkan dan mengelola data penduduk dan pendidikan. Dalam pengumpulan data penduduk dapat dilakukan melalui sensus penduduk di suatu wilayah. Sedangkan pengumulan data pendidikan dapat dilakukan dengan cara menyebarkan instrumen (format) pendataan pendidikan dan kebudayaan yang sudah dibakukan oleh badan penelitian dan pengembangan kementrian pendidikan dan kebudayaan atau dengan menggunakan data sekunder yang sudah dikumpulkan oleh petugas pendataan di lingkungan kementrian pendidikan dan kebudayaan. Matin, (2019:7-8)

Untuk memudahkan dalam memperoleh informasi, data yang sudah dikumpul hendaknya disajikan dengan menggunakan tabel (tabulasi) atau dibuat dalam bentuk diagram atau grafik. Beberapa teknik pengolahan dan analisis data yang digunakan dalam perencanaan pendidikan adalah "tabulasi, rasio, persentase, sparague multiplier, kohrt, proyeksi, dan efesiensi internal. Berikut ini akan dijelaskan tiga teknik yang ddisebutkan pertama (tabulasi, rasio, dan presentase).

a. Tabulasi Data

Tabulasi data adalah suatu kegiatan membuat tabel untuk menempatkan data pada tempat yang tepat sesuai keperluan, gunanya 
selain untuk efesiensi penggunaan tempat, juga untuk memudahkan pencarian informasi pada cakupan yang lebih luas. Matin, (2019:11)

b. Menghitung indikator dengan rasio dan presentase

Penggunaan perhitungan mencari angka perbandingan kelas dengan ruang kelas, perbandingan kelas dengan guru, dan mencari rata-rata jumlah murid untuk masing-masing kelas seperti pada contoh penggunaan "rasio". Rasio juga dapat digunakan untuk menghitung perbandingan murid dengan guru, beban mengajar guru, tingkat pelayanan sekolah, dan lain sebagainya. Matin, (2019:13)

\section{B. Proyeksi Kebutuhan Saranan Dan Prasarana}

Selain didasarkan kepada kebutuhan sarana dan prasarana pendidkan sesuai engan kedaan data pada masa lalu dan masa kini, perencanaan sarana dan prasarana pendidikan juga dapat ilakukan berdasarkan data pada masa yang akan datang sebagai hasil proyeksi. Proyeksi kebutuhan sar na dan prasarana pendidikan di masa depan mencangkup berbagai petimbangan. Mungkin membutuhkan keahlian teknik yang tinggi diluar kemampuan ahli perencanaan pendidikan. Meskipun demikian adalah tugas perencanaan pendidikan untuk mengetahui informasi penting apa saja yang dibutuhkan dalam rangka pembangunan atau mengkontruksi gedung sekolah dan sarana lainnya. Matin, (2019:17)

\section{PENGADAAN SARANA DAN PRASARANA PENDIDIKAN}

\section{A. Konsep Pengadaan Sarana dan Prasarana Pendidikan}

Pengadanaan sarana dan prasarana pendidikan adalah kegiatan penyediaan semua jenis sarana dan prasarana sesuai dengan kebutuhan dalam rangka mencapai tujuan pendidikan yang telah ditetapkan sebelumnya. Dalam konteks persekolahan, pengadaan sarana dan prasarana pendidikan merupakan segala kegiatan yang dilakukan dengan cara menyediakan semua keperluan barang atau jasa berdasarkan hasil perencanaan dengan maksud untuk menunjang kegiatan pembelajaran agar kegiatan pembelajaran dapat berjalan secara efektif dan efesien sesuai dengan tujuan yang diinginkan. Matin, (2019:21) 
B. Strategi Pengadaan Sarana dan Prasarana

Ada beberapa alternatif cara dalam pengadaan sarana dan prasarana pendidikan persekolahan. Beberapa alternatif cara pengadaan sarana dan prasarana pendidikan persekolahan tersebut adalah melalui :
a). Membeli
b). Mambuat sendiri
c). Bantuan atau hibah
d). Menyewa
e). Meminjam
f). Mendaur ulang
g). Menukar
h). Memperbaiki atau merekonstruksi kembali.
i). Proses lelang. Matin, (2019:22-26)

C. Prosedur pengadaan sarana dan prasana pendidikan

Prosedur pengadaan barang dan jasa harus mengacu kepaa keprs No. 80/2003 yang telah disempurnakan dengan permen no. 24/2007. Pengadaan sarana dan prasarana pendidikan di sekolah umumnya melalui prosedur sebagai berikut:

1. Penganalisis kebutuhan dan fungsi sarana dan prasarana.

2. Mengklasifikasi sarana dan prasarana uang dibutuhkan.

3. Membuat proposal pengadaan sarana dan prasarana yang ditujukan kepada pemerintah bagi sekolah negeri dan pihak yayasan bagi sekolah swasta.

4. Bila disetujui maka akan ditinjau dan dinilai kelayakannya untuk mendapat ersetujuan dari pihak yang dituju.

5. Setelah dikunjungi dan disetujuti maka sarana dan prasarana akan dikirim kesekola yang mengajukan permohonan pengadaan sarana dan prasarana tersebut. Matin, (2019:28) 
Contoh proses pengadaan sarana dan prasarana pendidikan disekolah adalah sebagai berikut : sekolah melakukan analisis kebutuhan, kemudian mengklasifikasikan dan membuat proposalyang ditujukan ke pemerintah melalui Dinas Tingkat II. Bila disetujui maka akan ditinjau dan dinilai kelayakannya untuk mendapat persetujuan dari pihak yang dituju. Apabila sudah disetujui biasanya dinas mengirim barang tersebut dengan sendirinya (dikirim dari Dinas Pendidikan Tk. II). Matin, (2019:28)

Proses pengadaan sarana dan prasarana pendidikan ada bermacam-macam cara tergantung dari jenis barang yang akan diadakan. Jenis-jenis sarana dan prasarana pendidikan dapat igolongkan ke dalam buku, alat, perabot, bangunan, dan tanah. Berikut ini dijelaskan proses pengadaan berbagai jenis sarana dan prasarana pendidikan terrsebut. Matin, (2019:29)

\section{Pengadaan Buku}

Salah satu tujuan negara adalah mencerdaskan kehidupan bangsa. Salah satu sarana untuk mencapai tujuan itu ialah tersedianya bahan bacaan yaitu buku, majalah, atau rekaman bahan pustaka lain melalui bacaan yang baik masyarakat dapat meningkatkan pengetahuannya, memperluas cakrawala pandangan hidupnya, memperbaiki budi pekertinya, meningkatkan serta memajukan kebudayaannya. Matin, (2019:30)

Membaca merupakan salah satu tuntutan dalam kehidupan masyarakat modern, membaca adalah sebuah aktivitas yang tidak asing bagi masyarakat, bahkan kegiatan membaca sudah diperkenalkan sejak usia dini. Dengan mambaca, kemampuan berpikir manusia akan semakin terasa dan berkembang. Ilmu pengetahuan pun akan bertambah dan meningkatkan kualitas sumber daya manusia terutam di era globalisasi ini. Sulfemi, (2019:1)

Jika pembelian buku dilakukan kepada penerbit/distributor/agen resmi dapat melalui cara penunjukan lansung dengan mengikuti ketentuan pada keppres No. 20/198 tentang penunjukan langsung pembelian buku denga nilai di atas Rp 20 juta melalui toko buku/suppler/imorter dilaksnakan dengan cara pelelangan. Pembelian buku sampai dengan 10 judul dan bernilai sampai 
dengan Rp 100 ribu dapat melakukan cara swakelola. Matin, (2019:30)

\section{Pengadaan Alat}

Alat yang dimaksud dalam hal ini terdiri atas alat-alat kantor dan alatalat pendidikan. Adapun yang trmasuk alat kantor ialah alat-alat ynng bisa digunakan di kantor sperti: mesin tulis, mesin hitung, mesin stensil, komputer, alat-alat pembersih dan sebagainya. Sedangkan yang termasuk dlam alat pendidikan ialah alat-alat yang secara fungsional digunakan dalam proses belajar mengajar seperti alat peraga, alat praktik, alat laboraturium, alat kesenian, alat olahraga dan sebagainya. Pengadaan alat kantor dan lat pendidikan dapat dilaksanakkan dengan cara:
a. Membeli
b. Membuat seniri
c. Menerima bantuan/hibah/hadiah

\section{Pengadaan Perabot}

Perabot ialah barang-barang yang berfungsi sebagai tempat untuk menulis, istirahat, tempat penyimpana alat atau bahan. Contoh : meja, kursi, lemari, rak, filling kabinet dan sebagainya. Alam pengadaan perabot sekolah, maka ada beberapa hal yang perlu dipertimbangkan seperti segi antronomentri, ergunomi, estetika, dann segi ekonomis.

a. Antronomi, artinya pengadaan perabot dengan memperhitungkan tinggi badan atau ukuran penggal-penggal tubuh pemakai (misalnya siswa dan tenaga kependidikan lainya).

b. Ergonomis, maksudnya perabot yang akan diadakann tersebut memeratikan segi kenyamanan, kesehatan, dan keamanan pemakai.

c. Estetis, yaitu perabot yang akan diadakan tersebut hendaknya menyenangkan untuk dipakai karena bentuk dan warnanya menarik.

d. Ekonomis, maksudnya perrabot bukan hanya berkaitan engan harganya tetapi merupakan transformasi wujud efesinsi dan efektivitas dalam pengadaan dan pendayagunaanya. Matin, (2019:32) 
Adapun untu engadaan perabot dapat dilakukan engan cara-cara berikut:

a. membeli

agar pembelian perabot dapat dilaksanakan sesui dengan kebutuhan dapat dipertanggungjawabkan maka perlu adanya suatu pedoman sebagai berikut :

1) Rencana kebutuan telah disetujui berdasarkan penelitan dan hitungan yang mendalam. Penelitian atas barang (survei) pada umumnya meliputi spetifikasi; Matin, (2019:32)

a) Buatan pabrik/negara mana dan taun pembuatannya.

b) Merk dagang.

c) Kapasitas

d) Bahan-bahan yang dipakai

e) Penyediaan suku cadang

f) Jaminan yang diberikan oleh penjual, agen pabrik

g) Cara pembayaran dan harga

h) Model.

2) Peraturan tentang pembelian, baik pembelian langsung mauun melalui tim pembelian.

3) Perabot yang akan dibeli daatt berbentuk sudah jadi atau yang belum jadi. Perabot yang belum jai perlu dibuat terlebi dahulu sesuai dengan kehendak pemohon.

4) Tentang pembelian perabot yang sudah jadi, kepala sekolah/proyek perlu membuat rencana kebutuhan, sesuai dengan syarat-syarat yang diperlukan.

5) Untuk pengadaan perbot yang belum jadi, maka keala sekolah/proyek perlu:

a) Menyusun kebutuhan 
b) Penunjukan konsultan perencanaan perabot

c) Menyusun syarat-syarat teknis sesuai dengan spesifikasi dan menyediakan gambar-gambar perabot yang akan dibeli

d) Membuat kontrak

e) Membuat berita acara serah terima perabot.

6) Pembelian perabot dapat dilakukan dengan lelang, penunjukan langsung dan penawaran. Matin, (2019:33)

b. Membuat Sendiri

Pengadaan perabot dengan membuat sendiri anya berlaku bagi sekolah dalam rangka untuk praktik, dan dapat dilaksanakan sesuai dengan kemampuan, terutama dalam al biaya yang tersedia, tenaga ahli yang dimiliki, peralatan yang dibutuhkan, pelaksanaan tugas yang dibebankan. Matin, (2019:33)

c. Menerima bantuan/hadiah.

Meneima bantuan dilaksanakan atas perjanjian dan persetujuan dari keua belah pihak (pemberi dan penerima) dan bantuan itu dapat berasal dari lembaga emerintaan, swasta, maupun perorangan. Matin, (2019:34)

\section{Pengadaan Bangunan}

Pengadaan bangunan milik negara adalah merupakan bagian dari pengadaan barang pada umumnya yang sala satunya meruakan kegiatan pengadaan prasarana sarana endiikan. Pengadaan bangunan gedung pada prinsipnya mempunyai tata cara yang sama dengan pengadaan barang-barang yang lain, bedanya adalah dalam pengadaan barang-barang peralatan biasnya barang-barangnya sudah jadi sehingga pengadaan dilakukan melalui pembelian, sedangkan pada pengadaan bangunan biasanya bangunan tersebut belum ada dan arus dibuat di tempat menurut ketentuan an keinginan pemberi tugas.

Pengadaan bangunan dapat dilaksanakan dengan beberapa cara seperti: dengan membangun bangunan baru, menyewa nbangunan, menerima hibah bangunan, dan menukar bangunan yang sudahh ada. Matin, (2019:34) 


\section{a. Membangun Bangunan Baru}

Pengadaan bangunan dengan membangun bangunan baru dapat meliputi:

1) Mendirikan, memperbaharui (rebilits/renovasi), memperluas, menguba dengan cara membongkar seluruhh atau sebagian bangunan gedung.

2) Pembuatan pagar alaman, jalan, penerasan alaman, pemasangan pompa/menara air, pengaaan listrik.

3) Kegiatan pekerjaan tanah yang meliputi; pengurukan tanah, perbaikan tana an penyelidikan tanah. Matin, (2019:34-35)

Membangun bangunan baru terdiri dari kegiatan-kegiatan : perencanaan, pelaksanaan, dan pengawasan lapangan. Sebelum perencanaan pmbangunan dilaksanakan, terlebih dahulu harus diadakan persiapan-persiapan yaitu pengumpulan data; pembuatanprogram kebutuhan bangunan/ruangan; pengarahan penugasan; (term of referencei); dan pengadaan tanah. Tahap berikutnya sesudah persiapan adalah perencanaan dan pelelangan geung. Perencanaan yang dimaksud adalahh perencanaan dan pelelangan geung. Matin, (2019)

\section{b. Membeli Bangunan}

Pengadaan bangunan melalui membeli bangunan yang sudah jadi mengikuti ketentuan sebagai berikut :

1) Pada prinsipnya membeli bangunan yang sudah jadi termasuk tananya tidak diperbolehkan. Tetapi ddalam hal-hal luar biasa, dapat diusulkan kepada Menteri keuangan dan ketua Bappenas dengan disertai alasan-alasan yang kuat melalui Menteri Pendidikan Nasional.

2) Setelah ada ersetujuan dan danya sudah terseia, selanjutnya dilakukan penawaran harga diri pemiliknya melalui panitia pembebasan Tanah setempat yang dibentuk berdasarkan keppres No. 80/2003.

3) Apabila antara harga penawaran dan harga penaaksiran panitia suda adda kecocokan, maka dapat langsung diselesaikan akta 
jual beli di depan Notaris/Pejabat pembuat Kta Tanah dan selanjutnya diselesaikan Balik Nama sertifikat tanah.

\section{c. Menyewa Bangunan}

Pengadaan bangunan melalui menyewa bangunan mengikuti ketentuan sebagai berikut :

1) Apabila diperlukan untuk keperluan gedung sekolah, gudang dan sebagainya, maka suatu instansi diperkenalkan untuk menyewa bangunan, dengan syarat anggaran untuk membayar sewa itu harus sudah tersedia lebi dahulu.

2) Untuk menetapkan besarnya sewa, ppemilik bangunan perlu dimintakan ppengesahan/penetapan lebih dahulu kepada panitia sewa menyewa atau kantor urusan perumahan setempat.

3) Setelah ditetapkan sewanya, dibuat surat perjanjian (kontrak) antara pihak penjual dan pihak yang menyewakan, jika dianggap perlu dilakukan dengan akta notaris.

4) Gedung sekolah milik swasta (bersubsidi) dahulu pernah mendapat subsidi dari pemerinta cq Departemen Pendidikan Nasional, apabila dipakai oleh sekolah negri, berdasarkan peraturan subsidi yang sekarang masih berlaku tidak perlu dibayar sewanya, tetapi pemakai wajib memelihara bangunan tersebut sebagaimana mestinya. Matin, (2019:37-38)

\section{d. Menerima Hibah Bangunan}

Pengadaan bangunan melalui menerima hibahh bangunan mengikuti ketentuan sebagai berikut:

1) Departemen Pendidikan Nasional dapat menerima bangunan berikut tanah dari pihak lain (pemerintah Daerah/Swasta)

2) Agar ada dasar hukumnya, sebaiknya pelaksanaanya dilakukan dengan Akta Notaris Pejabat Pembuat Akta setempat. Matin, (2019:38)

\section{e. Menukar Barang}


Pengadaan bangunan melalui menukar bangunan mengikuti ketentuan sebagai berikut :

1) Penukaran bangunan atau pemindah tanganan barang tidak bergerak milik negara ada umumnya diatur dalam keputusan presiden tentang pelaksanaan APBN, yaitu segala sesuatu arus mendaat persetuuan menteri keuangan terlebih dahulu.

2) Bangunan milik begara yang tidak memenuhi fungsinya lagi, lokasinya terlalu ramai atau tanahnya terlalu sempit untuk diadakan perluasan bangunan, dapat diusulkan untuk ditukarkan dengan bangunan milik pihak lain yang sudah jai atau masih akan dibangun dilokasi lain usul penukaran diajukan kepada Menteri Pendidikan Nasional dengan dilampiri:

a) Alasan-alasan penukaran

b) Penaksiran sementara harga tanah/bangunan lama

c) Penaksiran sementara harga tanah/bangunan baru

d) Surat-surat pemilikan tanah/bangunan lama

e) Gambar situasi/denah dari tanah/bangunan lama

f) Gambar situasi/denah dari tanah/bangunan baru. Matin, (2019:38)

\section{Pengadaan Tanah}

Pengadaan tanah oleh pemerintah dapat berasal ddari tanah yang dikuasai oleh negara atau tanah yang sudah dalam penguasaan pihak lain, teradap tanah negara, Kementrian Pendidikan dan Kebudayaan daat mengajukan permintaan ak pakai atau hak engelolaan menurut proseduryang diatur dalam peraturan Menteri Dalam Negeri Nomor 5 Tahunn 1971. Terhadap tanah yang sudah dikuasai pihak lain, terlebih dahulu melalui prosedur pembelian tanah dan atau pelepasan hak tanah atau penukaran (ruilslag). Matin, (2019:39) 


\section{PEMANFAATAN SARANA DAN PRSARANA PENDIDIKAN}

Dalam pemanfaatan untuk proses belajar mengajar, sudah disimpan dengan teratur dan dijaga dengan baik sesuai dengan ketentuan-ketentuan yang sudah disepakati oleh sekolah. Pihak sekolah sudah menjaga semua sarana dan prasarana dengan baik. Meskipun ada kerusakankerusakan dikarenakan banyak barangbarang yang sudah tidak dapat dipakai lagi, sifatnya haus dan memang sudah tidak dapat dimanfaatkan lagi karena barangnya sudah tua sehingga kalau dipakai akan tidak efektif lagi dan menimbulkan cidera, selain itu juga ada faktor lain dari luar yang dilakukan masyarakat sekitar terhadap ketidaksenangan oleh sekolah sehingga banyak barang-barang yang apabila di letakkan diluar ruang akan dan diluar sekolah makan akan sengaja dirusak atau diambil untuk kepentingan sendiri. Sehingga pihak sekolah biasanya sehabis pulang sekolah langsung menyimpan barang-barang tersebut ke kelas, dan ke dalam ruang-ruang yang ada di sekolah. Dengan pemakaian perlengkapan pendidikan harus memperhatikan 2 (dua) prinsip yaitu prinsip efektifitas dan prinsip efesiensi yang berarti bahwa semua pemakaian sarana dan prasarana pendidikan di sekolah harus digunakan semata-mata dalam rangka memperlancar pencapaian tujuan pendidikan sekolah (Darmastuti dan Karwanto 2014). Trisnawati dkk,(2019:66)

\section{PEMELIHARAAN SARANA DAN PRASARANA PENDIDIKAN}

Pemeliharaan diantaranya mengoptimalkan usia pakai peralatan, menjamin kesiapan operasional peralatan untuk mendukung kelancaran pekerjaan sehingga diperoleh hasil yang optimal. Pemeliharaan sudah dilakukan dengan baik sesuai dengan alokasi perawatanperawatan terhadap barang, melindungi terhadap barang-barang yang penting, memperbaiki, servis, mendata semua inventaris, menyimpan dan digudangkan dengan baik, sehingga dalam pengawasan sarana dan prasarana yang diterapkan oleh sekolah dapat meminimalisir keluarnya biaya agar proses pembelajaran berjalan lancar dan baik tanpa ada hambatan. Pemeliharaan dilakukan secara terus menerus untuk menjaga agar barang milik sekolah selalu dalam keadaan baik dan siap untuk digunakan, pemeliharaan sarana dan prasarana pendidikan memiliki peranan yang sangat penting karena dengan adanya pemeliharaan yang baik maka penyelenggaraan akan berjalan baik pula (Megasari 2014). Peran pimpinan sekolah, wakilnya, guru-guru dan siswa-siswa dalam menjaga barang-barang milik sekolah sangat berperan aktif, selalu saling mengingatkan agar barang-barang sekolah yang sudah digunakan dapat simpan kembali dalam gudang atau 
tempat yang aman untuk menyimpan barang-barang sekolah tersebut. Perawatan dan pemeliharaan masing-masing ruang kelas merupakan tanggung jawab dari rombongan belajar serta pihak pengelola sarana dan prasarana pendidikan (Sutama dan Rahayu 2015). Trisnawati dkk,(2019:66-67)

\section{INVENTARISASI SARANA DAN PRASARANA PENDIDIKAN}

\section{A. Konsep inventarisasi Sarana dan Prasarana Pendidikan}

Inventaris sarana dan prasarana pendidikan adala kegiatan pencatatan atau pendaftaran barang-barang milik lembaga (sekolah) ke dalam suatu daftar inventaris barangg secara tertib dan teratur menurut ketentuan dan tata cara yang berlaku. Matin, (2019:55)

B. Tujuan Inventarisasi Sarana dan Prasarana Pendidikan

1. Untuk menjaga dan menciptkan tata tertib administrasi sarana dan prasarana yang dimiliki oleh suatu sekola

2. Untuk menghematan keuangan sekol biik dlam pengadaan maupun untuk pemeliharaan dan penghapusan sarana an prasarana sekolah.

3. Sebagai pedomaan untuk menghitung kekayaan suatau sekola dalam bentuk materil yang dapat dinilai dengan uang.

4. Untuk memudahkan pengawasan dan pengendalian sarana an prasarana yang dimiliki oleh suatu sekolah.

C. Manfaat Inventarisasi Sarana dan Prasaranaa Pendidikan

1. Menyediakan data dan informasi dalam rangka menentukan kebutuan dan menyusun rencana kebutuan barang.

2. Mmberikan data dan informasi untuk ijadikn baan/pedoman dalam pengarahan pengadaan barang.

3. Memberikan data ddan informasi untuk dijadikan bahan/pedoman dalam penyaluran barangg.

4. Memberikan data dan informasi dalam menentukan keadaan barang (tua,rusak, lebi) sebagai dasar untuk menetapkan penghapusannya. 
5. Memberikan data dan informasi dalam rangka memudahkan pengawasan dan pengendalian barang. Matin, (2019:56)

\section{Tata Cara Pelaksanaan Inventarisasi}

Tata cara pelaksanaan inventarisasi adalah kegiatan mencatat sarana dan prasarana ke dalam buku daftar invetaris dan membuat laporannya pada pihak terkait. Ada sejumlah buku kartu daftar barang inventaris yang digunakanyaitu buku induk barann inventaris buku golongan barang inventaris, buku catatan barang non inventaris, daftar laporan mutasi barang inventaris, dan kartu inventaris barang buku-buku dan kartu inventaris barang tersebut. Matin, (2019:56).

\section{PENGHAPUSAN SARANA DAN PRASARANA PENDIDIKAN}

A. Konsep Penghapusan Sarana dan Prasarana Pendidikan

Penghapusan sarana dan prasarana pendidikan merupakan kegiatan penghapusan sarana dan prasarana pendidikan dari pertanggungjawaban yang berlaku dengan alasan yang dapat dipetanggung jawabkan. Secara lebih operasioonal penghapusan sarana dan prasarana pendidikan adalah merupakan proses kegiatann yang berujuan untuk megeluarkan atau menghilangkan sarana dan prasarana pendidikan dari daftar inventaris barang karena sarana dan prasarana tersebut sudah dianggap tidak berfungsi sebagaimana yang diharapkan terutama kepentingan pelaksanaan pembelajaran di sekolah.

Penghapusan sarana dan prasarana pendidikan dilakukan berdasarkan peraturan perundang-undangan yang berlaku. Matin, (2019:127)

B. Tujuan Penghapusan Sarana dan Prasarana Pendidikan

Pengapusan sarana dan prasarana pendidikan pada dasarnya bertuujun untuk:

1. Mencegah atau sekurang-kurangnya membatasi kerugian/pemborosan biaya pemeliaraan sarana dan prasarana yang 
kondisinya semakin buruk, berlebihan atau rusak dan sudah tidak dapat digunakan lagi.

2. Meringankan beban kerja pelaksanaan inventaris barang.

3. Membebaskan ruangan dari penumpukan barang-barang yang tidak dapat digunakan lagi dan,

4. Membebaskan barang dari tanggung jawab pengurusan kerja. Matin, (2019:128)

C. Syarat-syarat Penghapusan Sarana dan Prasarana Pendidikan

1. Sarana dan prasarrana dalam keadaan sudah tua atau rusak berat sehingga tidak dapat diperbaiki atau dipergunakan

2. Perbaikan sarana dan prasarana akan menelann biaya yang besar sehingga merupakan pemborosan

3. Secara tenisi dan ekonomi kegunaannya tidak seimbang denan besarnya biaya pemeliharaan

4. Sarana dan prasarana tersebut tidak sesuai lagi dengan kebutuhan masa kini

5. Adanya penyusutan barang di luar kekuasaan pengurus barang (misalnyabarang kimia)

6. Jumlah barang berlebi sehingga jika disimpan lebh lama akan bertambah dan tak terpakai lagi

7. Sarana dan prasarana dicuri, terbakar, dan atau musnah sebagai akibat bencana alam. Matin, (2019:128)

D. Mekanisme Penghapusan Sarana Prasarana Pendidikan

Dalam pelaksanaan penghapusan sarana dan prasarana pendidikan dikenal dua mekanisme yaitu penghapusan melalui lelang dan melalui pemusnahan. Matin, (2019:129)

E. Tata Cara Penghapusan sarana dan Prasarana Pendidikan

Di kategorikan lima cara yaitu: 
1. Penghapusan sarana dan prasarana pendidikan diakibatkan karena saran dan prasarana tersebut mengalami rusak berat, sudah tua, dan atau berlebih

2. Penghapusan gedung sekolah rusak berat

3. Pengapusan barang inventaris sekolah karena dicuri, hilang, dan atau terbakar

4. Penghapusan rumh dinas

5. Penghapusan sarana dan prasarana pendidikan karena bencana alam. Matin, (2019:130) 


\section{PENUTUP}

\section{KESIMPULAN}

Sarana dan prasarana pendidikan suatu faktor menunjang dalam proses kagiatan belajar mengajar, dalam suatu instansi sekolah sarana dan prasarana nya terpenuhi maka proses belajar mengajar nya pun akan efektif dan efesien.

Sarana dan prasrana pendidikan merupakan salah satu sumber daya yang penting dalam menunjang proses pembelajaran di sekolah. Keberhasilan program pendidikan di sekolah sangat dipengaruhi oleh kondisi sarana dan prasarana pendidikan yang dimiliki sekolah dan oleh optimalisasi pengelolaan dan pemanfaatannya.

Dalam persektif pemerintah, kegiatan manajemen sarana dan pendidikan setidak-tidaknya memiliki delapan mata rantai kegiatan yaitu : 1) perencanaan sarana dan rasarana pendidikan; 2) pengadaan sarana dan prasarana pendidikan; 3) penyaluran sarana dan prasaran pendidikan; 4) penyimpanan sarana dan prasarana pendidikan; 5) pemeliharaan sarana dan prasarana pendidikan; 6) pendayagunaan sarana dan prasarana pendidikan; 7) inventarisasi sarana dan prasarana pendidikan; 8) penghapusan sarana dan prasarana pendidikan dengan tujuan untuk mencapai tingkat pengamanan yang semaksimal mungkin terhada kekayaan milik negara. 


\section{DAFTAR PUSTAKA}

1. Sulfemi, W. B,. \& Teti Luthfianti (2019). Asosiatif Layanan Tenaga Perpustakaan Sekolah Dengan Motivasi Membaca Siswa Di Kabuaten Bogor. Bogor: Administrasi Pendidikan STKIP Muhammadiyah Bogor.

2. Matin, dan Nurhattati Fuad. 2016. Manajemen Sarana dan Prasarana Pendidikan. Depok: PT. Rajagrafindo Persada

3. Trisnawati, dkk. (2019). Manajemen Sarana Dan Prasarana Pendidikan Dalam Meningkatkan Mutu Pembelajaran Di Sd Negeri Lamteubee Aceh Besar. Jurnal Magister Administrasi Pendidikan. 7(1) : 62-69 
Soal PG

1. Berikut ini rantai kegiatan dalam manajemen sara dan prasarana pendidikan adalah...
A. Perencanaan Sarana dan Prasarana Pendidikan
B. Penyimpanan Sarana dan Prasarana Pendidikan
C. Pemeliharaan Sarana dan prasarana Pendidikan
D. Semua jawaban benar

2. Berikut ini yang termasuk dalam standar sarana dan prasarana pendidikan dalam Nomor 19 Tahun 2005 Junto Nomor 32 Tahun 2013 adalah...
A. Setiap satuan pendidikan wajib memiliki sarana dan prasarana yang meliputi perabot, peralatan endidikan, media, buku, dan sumber belajar lainnya.
B. Setiap sekolah harus memiliki siswa yang berkreatif
C. Setiap sekolah harus memiliki transpostasi untuk mengantar jemput siswa
D. Setiap sekolah harus menfasilitasi bagi siswa yang cacat.

3. Dalam perencanaan kebutuhan sarana dan prasarana pendidikan yaitu?
A. Analisis
B. Pengelolaan
C. Perencanaan
D. Pelaksanaan

4. Pengadaan Sarana dan Prasarana Pendidikan meliputi kecuali
A. Konsep Sarana dan Prasarana Pendidikan
B. Pelaksanaan Sarana dn Prasarana pendidikan
C. Strategi Sarana dan Prasarana Pendidikan
D. Prosedur Sarana dan Prasarana Pendidikan 
5. Apa saja yang meliputi dalam proses pengadaan sarana dan prasarana pendidikan $k e c u a l i . .$.
A. Pengadaan buku
B. Pengadaan alat
C. Pengadaan internet
D. Pengadaan perabot

6. Inventarisasi Sarana dan Prasarana Pendidikan meliputi...
A. Konsep Inventarisasi Sarana dan Prasarana pendidikan
B. Tujuan Inventarisasi Sarana dan Prasarana Pendidikan
C. Manfaat Inventarisasi Saearana dan Prasarana Pendidikan
D. Semua jawaban benar

7. Penghapusan Sarana dan Prasarana Pendidikan meliputi...
A. Konsep penghapusan Sarana dan Prasarana Pendidikan
B. Tujuan penghapusan Sarana dan Prasarana Pendidikan
C. Semua jawaban benar
D. Tata cara pengahapusan Sarana dan Prasarana Pendidikan

8. Pengadanaan sarana dan prasarana pendidikan adalah kegiatan penyediaan semua jenis sarana dan prasarana sesuai dengan kebutuhan dalam rangka mencapai tujuan pendidikan yang telah ditetapkan sebelumnya. Yang sesuai dengan pernyataan berikut ini dalam pengadaan sarana dan prasarana pendidikan adalah...
A. Konsep pengadaan Sarana dan Prasarana Pendidikan
B. Strategi pengadaan Sarana dan Prasarana Pendidikan
C. Prosedur pengadaan Sarana dan Prasarana Pendidikan
D. Semua jawaban salah

9. Dibawah ini yang termasuk tata cara penghapusan Sarana dan Prasarana Pendidikan adalah... 

A. Penghapusan gedung sekolah rusak berat
B. Pengapusan barang inventaris sekolah karena dicuri, hilang, dan atau terbakar
C. Semua jawaban benar
D. Penghapusan rumah dinas

10. Dalam pengadaan bangunan sarana dan prasarana meliputi...
A. Membangun bangunan baru
B. Membeli bangunan
C. Menyewa bangunan
D. Semua jawaban benar

\section{Soal Essay}

1. Sebutkan tujuan penghapusan Sarana dan Prasarana Pendidikan!

2. Apa yang dimaksud dengan pengadaan perabot pada Sarana dan Prasarana pendidikan?

3. Apa yang dimaksud dengan tabulasi data?

4. Jelaskan apa itu Pemeliharaan Sarana dan Prasarana Pendidikan!

5. Sebutkan prosedur apa saja yang ada pada pengadaan Sarana dan Prasarana Pendidikan! 
Jawaban PG :

1. D

2. $\mathrm{A}$

3. $\mathrm{A}$

4. $\mathrm{B}$

5. $\mathrm{C}$
6. D

7. $\mathrm{C}$

8. A

9. B

10. D

Jawaban Essay

1. a) Mencegah atau sekurang kurangnya membatasi kerugian/pemborosan biaya pemeliharaan sarana dan prasarana yang kondisinya semakin memburuk, berlebihan atau rusak dan sudah tidak dapat digunakan lagi.

b) Meringankan beban kerja pelaksanaan inventaris barang

c) Membebaskan ruangan dari penumpukan barang-barang yang tidak dapat digunakan lagi.

2. Perabot ialah barang-barang yang berfungsi sebagai tempat untuk menulis, istirahat, tempat penyimpana alat atau bahan. Contoh : meja, kursi, lemari, rak, filling kabinet dan sebagainya.

3. Tabulasi data adalah suatu kegiatan membuat tabel untuk menempatkan data pada tempat yang tepat sesuai keperluan, gunanya selain untuk efesiensi penggunaan tempat, juga untuk memudahkan pencarian informasi pada cakupan yang lebih luas.

4. Pemeliharaan diantaranya mengoptimalkan usia pakai peralatan, menjamin kesiapan operasional peralatan untuk mendukung kelancaran pekerjaan sehingga diperoleh hasil yang optimal.

5. a) Penganalisis kebutuhan dan fungsi sarana dan prasarana.

b) Mengklasifikasi sarana dan prasarana uang dibutuhkan.

c) Membuat proposal pengadaan sarana dan prasarana yang ditujukan kepada pemerintah bagi sekolah negeri dan pihak yayasan bagi sekolah swasta. 
d) Bila disetujui maka akan ditinjau dan dinilai kelayakannya untuk mendapat ersetujuan dari pihak yang dituju.

e) Setelah dikunjungi dan disetujuti maka sarana dan prasarana akan dikirim kesekola yang mengajukan permohonan pengadaan sarana dan prasarana tersebut. 